\title{
Effectiveness of capsaicin containing dried habanero pepper extract in the treatment of primary hepatic cancer in geriatric dogs
}

\author{
PIOTR DĘBIAK, DAGMARA GADOMSKA*, ANNA ŚMIECH**, \\ JERZY ZIĘTEK ${ }^{* * *}$, PAWE Ł $Ł Y P{ }^{* * *}$, ANNA ŁOJSZCZYK-SZCZEPANIAK, \\ STANISŁAW WINIARCZYK ${ }^{* * *}$, ŁUKASZ ADASZEK ${ }^{* * *}$ \\ Department and Clinic of Animal Surgery, Laboratory of Radiology and Ultrasonography, \\ **Sub-Department of Pathomorphology and Forensic Veterinary Medicine, \\ ***Department of Epizootiology and Clinic of Infectious Diseases, Faculty of Veterinary Medicine, \\ University of Life Sciences in Lublin, Głęboka 30, 20-612 Lublin, Poland
}

*ARKONA L.F.S, Nasutów 21, 21-025 Nasutów, Poland

Dębiak P., Gadomska D., Śmiech A., Ziętek J., Łyp P., Łojszczyk-Szczepaniak A., Winiarczyk S., Adaszek Ł. Effectiveness of capsaicin containing dried habanero pepper extract in the treatment of primary hepatic cancer in geriatric dogs

Summary

The study was aimed at the preliminary clinical assessment of the anti-cancer efficacy of a dietary supplement based on the extract of habanero peppers containing capsaicin in dogs with primary hepatic cancer. 24 dogs with primary hepatic cancer, divided into two groups, were followed up during the study. Group I included 16 dogs receiving a dietary supplement based on capsaicin-containing habanero peppers, while group II consisted of $8 \mathrm{dogs}$ that did not receive any veterinary treatment. The dogs were subjected to clinical examination, ultrasound imaging as well as biochemical and haematological analyses. Patient survival was determined in both groups. An autopsy was performed in all animals that died or were euthanised, and tumour samples were collected for histopathological examination, on the basis of which the type of neoplasm was finally determined. Survival of dogs in group I ranged from 54 to 285 days (178.6 days on average). Survival of dogs in group II was 32-128 days ( 76.5 days on average). In none of the dogs classified to group I that had single tumours did the size of the lesion increase during supplement administration, and in the case of two dogs that were receiving the preparation for a long time (188 and 285 days), their liver tumours actually shrank. In all dogs from group II that had single tumours, the size of the lesions increased in the course of the observation. The preliminary clinical observations by the authors indicate that the capsaicin-containing habanero pepper extract exhibits favourable effects on liver tumours in dogs and is well tolerated by the animals, thus the obtained results are a good sign for future studies on alternative medications used in dog oncology.

Keywords: capsaicin, liver tumours, dogs

Primary hepatic tumours constitute $0.6-1.3 \%$ of all tumours in dogs and $1.0-2.3 \%$ in cats. These neoplasms may originate in hepatic cells or bile ducts. Less frequently, they arise from neuroendocrine and mesenchymal tissue. Hepatocellular carcinoma is the most frequently diagnosed type of hepatic cancer, constituting $50 \%$ of primary tumours of this organ. Canine hepatic cancer is most often diagnosed in geriatric patients (mean age of 10-11 years), regardless of pedigree and gender. These tumours may exhibit a varied histopathological picture. They often occur in the form of a single tumour, in most cases confined to one hepatic lobe. They can also take a multinodular form characterised with the presence of multiple nodules spread over several hepatic lobes. The third form are infiltrating tumours involving several hepatic lobes. The clinical symptoms associated with hepatic cancer are usually non-specific. In about $25 \%$ of dogs, physical examination does not reveal any irregularities and the only indication for the organ imaging is the detection of increased serum hepatic enzyme activity. If clinical symptoms do appear it means that either the liver parenchyma or bile ducts have been damaged. This is manifested by loss of appetite, vomiting or diar- 
rhoea, polyuria and excessive thirst, apathy and weight loss. Less frequent symptoms are ascites, jaundice and exercise intolerance (9).

Primary hepatic cancer is treated by surgical excision. The decision to perform the surgery is made on the basis of the general condition of the patient, the type and size of tumour as well as metastasis. Chemotherapy is of limited use and should be considered only in the case of inoperable tumours and infiltrating or widespread nodules involving several hepatic lobes. The most frequently used chemotherapy regimens are CHOP (combination of cyclophosphamide, hydroxydaunorubicin (also called doxorubicin), oncovin (vincristine) and prednisone or prednisolone), COP (cyclophosphamide, vincristine and prednisolone), or administration of doxorubicin alone (9). Recently, in human medicine, much attention has been devoted to the application of capsaicin in the treatment of hepatic cancer in people $(5,13,16)$. Capsaicin (8-methyl"N"-vanillyl-6-nonenamide) is an organic alkaloid compound derived from plants belonging to the genus Capsicum. Relatively large amounts of capsaicin are present in fruits of various pepper varieties, and the compound itself is responsible for the spicy taste of this plant. Capsaicin bonds with TRPV1 (transient receptor potential vanilloid subtype 1) (7), which is present in large amounts in the hypothalamus, at the endings of sensory neurons, in the dorsal root ganglia, as well as the trigeminal nerve. This receptor is also present in the kidneys, liver, bladder and pancreas (19). Capsaicin, after bonding with the TRPV1 receptor, causes the cation channel to open, the result of which is the flow of cations to the inside of the cell and its depolarisation. The resulting action potential is passed to the spinal cord and is responsible for the feeling of warmth and pain. Capsaicin may dilate skin vessels and increase heat exchange, which results in the development of hypothermia. On the other hand, this alkaloid may cause increased metabolism, which stimulates heat generation in the body and increase of internal body temperature (11).

It has been proven that capsaicin modulates the metabolism of carcinogenic and mutagenic compounds, which has made this alkaloid an object of study for oncologists who began to consider it a substance which could be used in cancer prevention and therapy. In human medicine, it has been proven that capsaicin is effective in cancer therapy, including cancer of breast, pancreas, bladder, or prostate $(8,10,23,24)$. In veterinary medicine, the research on habanero pepper extract and capsaicin itself has to date been limited mainly to the safety of its application in laboratory animals (11). Its efficiency has also been confirmed in the treatment of various tumours in dogs (1).

The study is aimed at the preliminary clinical assessment of the anti-cancer efficacy of a dietary supplement based on the extract of habanero peppers containing capsaicin in dogs with primary hepatic tumours.

\section{Material and methods}

Animals. The study was performed in 2012-2017. It involved 53 dogs aged $8-15$ years with hepatic tumours diagnosed in vivo on the basis of clinical examination and ultrasound imaging of the abdominal cavity (Fig. 1, 2, and 3).

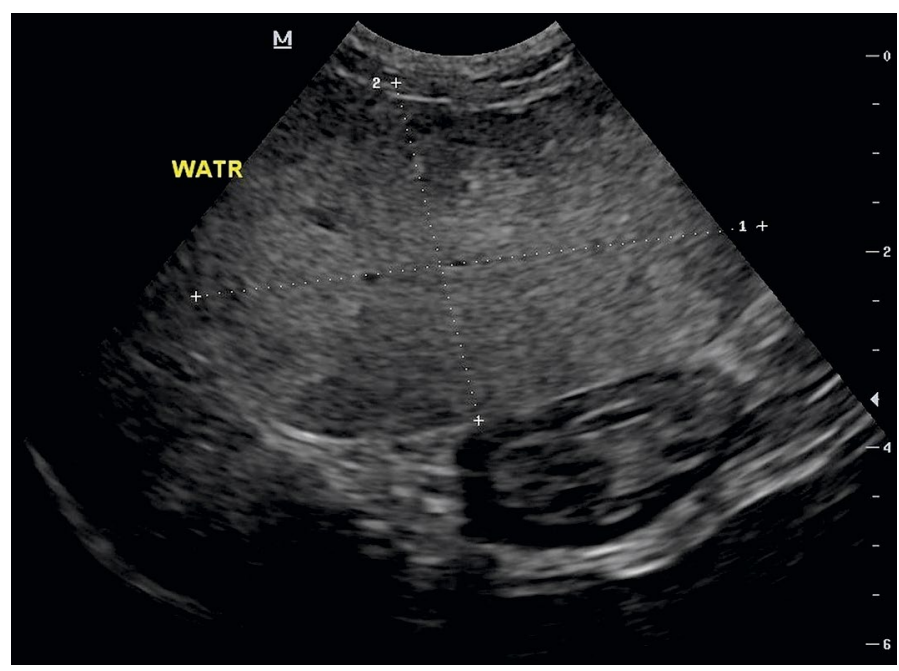

Fig. 1. Result of USG examination - single tumour in hepatic lobe

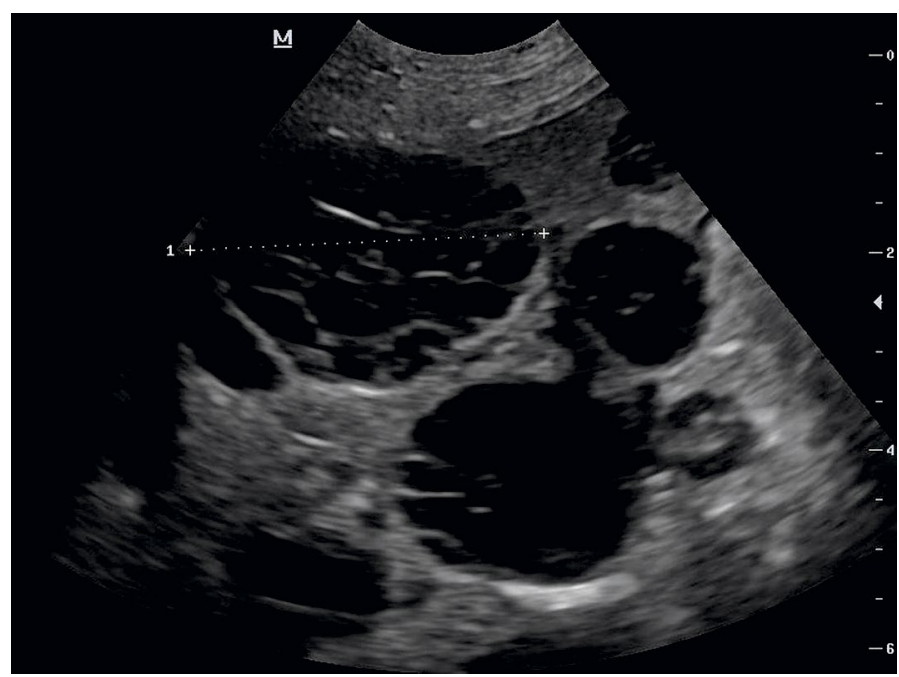

Fig. 2. Results of USG examination of the abdomen - multiple nodules spread over hepatic lobe

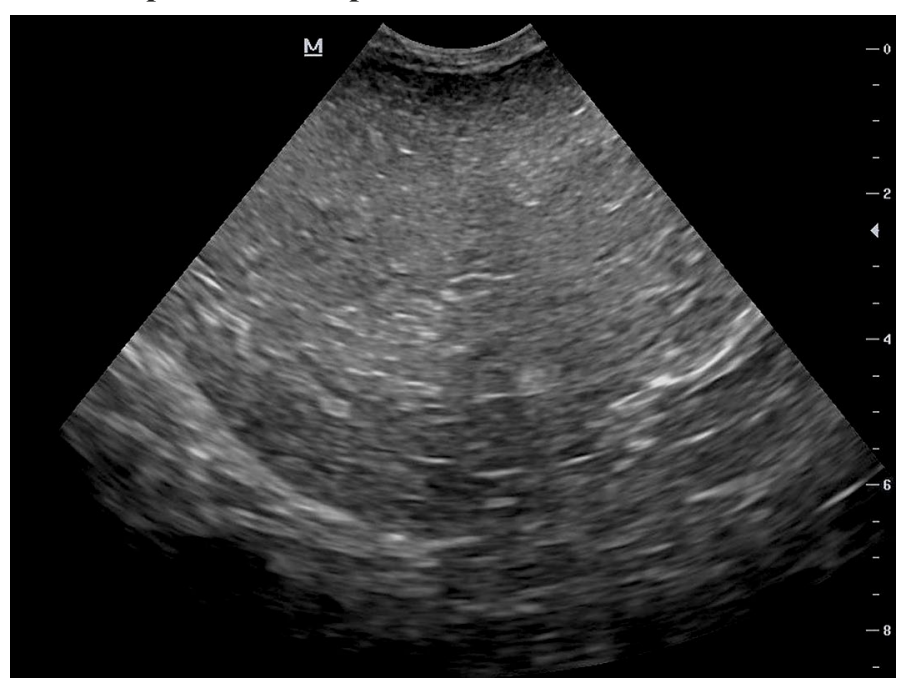

Fig. 3. Results of USG examination of the abdomen - infiltrating tumours in hepatic lobe 
Tab. 1. Description of the studied dogs

\begin{tabular}{|c|c|c|c|c|c|c|c|}
\hline No. & Breed & $\begin{array}{c}\text { Age } \\
\text { (years) }\end{array}$ & Gender & $\begin{array}{l}\text { Histopathological } \\
\text { examination }\end{array}$ & $\begin{array}{l}\text { Character and dimensions } \\
\text { of the lesions at the beginning } \\
\text { of treatment }\end{array}$ & $\begin{array}{l}\text { Survival } \\
\text { (days) }\end{array}$ & $\begin{array}{l}\text { Character and dimensions of the } \\
\text { lesions at the end of treatment }\end{array}$ \\
\hline \multicolumn{8}{|c|}{ Group 1} \\
\hline 1 & Mixed breed & 10 & Male & $\begin{array}{l}\text { Hepato-cellular } \\
\text { carcinoma }\end{array}$ & Infiltration & 233 & No change \\
\hline 2 & Mixed breed & 9 & Female & $\begin{array}{l}\text { Hepato-cellular } \\
\text { carcinoma }\end{array}$ & Infiltration & 158 & $\begin{array}{l}\text { Metastasis to lymphatic glands of } \\
\text { the hepatic hilum }\end{array}$ \\
\hline 3 & Doberman & 11 & Female & $\begin{array}{l}\text { Hepato-cellular } \\
\text { carcinoma }\end{array}$ & Single tumour $2.1 \mathrm{~cm} \times 4.2 \mathrm{~cm}$ & 292 & $\begin{array}{l}\text { No changes Metastasis to } \\
\text { lymphatic glands of the hepatic } \\
\text { hilum }\end{array}$ \\
\hline 4 & German Shepherd & 12 & Male & Biliary carcinoma & Infiltration & $\begin{array}{c}184 \\
\text { (euthanasia) }\end{array}$ & $\begin{array}{l}\text { Metastasis to lymphatic glands of } \\
\text { the hepatic hilum }\end{array}$ \\
\hline 5 & Beagle & 9 & Female & $\begin{array}{l}\text { Hepato-cellular } \\
\text { carcinoma }\end{array}$ & $\begin{array}{l}\text { Disseminated tumours in hepatic } \\
\text { lobes }\end{array}$ & 222 & $\begin{array}{l}\text { Metastasis to lymphatic glands of } \\
\text { the hepatic hilum }\end{array}$ \\
\hline 6 & Mixed breed & 14 & Male & $\begin{array}{l}\text { Hepato-cellular } \\
\text { carcinoma }\end{array}$ & $\begin{array}{l}\text { Disseminated tumours in hepatic } \\
\text { lobes }\end{array}$ & 215 & No change \\
\hline 7 & Schnauzer & 14 & Male & Biliary duct cancer & Infiltration & 127 & No change \\
\hline 8 & Mixed breed & 12 & Male & $\begin{array}{l}\text { Hepato-cellular } \\
\text { carcinoma }\end{array}$ & $\begin{array}{l}\text { Disseminated tumours in hepatic } \\
\text { lobes }\end{array}$ & $\begin{array}{c}195 \\
\text { (euthanasia) }\end{array}$ & $\begin{array}{l}\text { Metastasis to lymphatic glands of } \\
\text { the hepatic hilum }\end{array}$ \\
\hline 9 & Mixed breed & 10 & Female & Sarcoma & Infiltration & $\begin{array}{c}93 \\
\text { (euthanasia) }\end{array}$ & Metastasis in the lungs \\
\hline 10 & Great Dane & 8 & Male & $\begin{array}{l}\text { Hepato-cellular } \\
\text { carcinoma }\end{array}$ & Single tumour $3.3 \mathrm{~cm} \times 5.0 \mathrm{~cm}$ & 285 & $\begin{array}{l}\text { The tumour decreased to the size } \\
\text { of } 2 \mathrm{~cm} \times 2.5 \mathrm{~cm}\end{array}$ \\
\hline 11 & Cocker Spaniel & 8 & Female & $\begin{array}{l}\text { Hepato-cellular } \\
\text { carcinoma }\end{array}$ & Single tumour $2.5 \mathrm{~cm} \times 2.2 \mathrm{~cm}$ & 251 & No change \\
\hline 12 & Irish Setter & 15 & Male & $\begin{array}{l}\text { Hepato-cellular } \\
\text { carcinoma }\end{array}$ & Single tumour $4.7 \mathrm{~cm} \times 2.1 \mathrm{~cm}$ & 188 & $\begin{array}{l}\text { The tumour decreased to the size } \\
\text { of } 3 \mathrm{~cm} \times 2 \mathrm{~cm}\end{array}$ \\
\hline 13 & Dachshund & 13 & Female & Biliary duct cancer & Infiltration & $\begin{array}{c}54 \\
\text { (euthanasia) }\end{array}$ & $\begin{array}{l}\text { Metastasis to lymphatic glands of } \\
\text { the hepatic hilum }\end{array}$ \\
\hline 14 & Mixed breed & 9 & Female & Biliary duct cancer & Infiltration & $\begin{array}{c}86 \\
\text { (euthanasia) }\end{array}$ & Metastasis in the lungs \\
\hline 15 & Mixed breed & 10 & Male & $\begin{array}{l}\text { Hepato-cellular } \\
\text { carcinoma }\end{array}$ & $\begin{array}{l}\text { Disseminated tumours in hepatic } \\
\text { lobes }\end{array}$ & $\begin{array}{c}133 \\
\text { (euthanasia) }\end{array}$ & $\begin{array}{l}\text { Metastasis to lymphatic glands of } \\
\text { the hepatic hilum }\end{array}$ \\
\hline 16 & Dachshund & 13 & Male & $\begin{array}{l}\text { Hepato-cellular } \\
\text { carcinoma }\end{array}$ & Single tumour $1.5 \mathrm{~cm} \times 2.3 \mathrm{~cm}$ & 141 & No change \\
\hline \multicolumn{8}{|c|}{ Group 2} \\
\hline 17 & Alaskan Malamute & 10 & Male & $\begin{array}{l}\text { Hepato-cellular } \\
\text { carcinoma }\end{array}$ & $\begin{array}{l}\text { Disseminated tumours in hepatic } \\
\text { lobes }\end{array}$ & 62 & $\begin{array}{l}\text { Metastasis to lymphatic glands of } \\
\text { the hepatic hilum }\end{array}$ \\
\hline 18 & Mixed breed & 10 & Male & $\begin{array}{l}\text { Hepato-cellular } \\
\text { carcinoma }\end{array}$ & $\begin{array}{l}\text { Disseminated tumours in hepatic } \\
\text { lobes }\end{array}$ & 109 & No change \\
\hline 19 & Boxer & 14 & Male & $\begin{array}{l}\text { Hepato-cellular } \\
\text { carcinoma }\end{array}$ & Single tumour $3.0 \mathrm{~cm} \times 3.3 \mathrm{~cm}$ & $\begin{array}{c}128 \\
\text { (euthanasia) }\end{array}$ & $\begin{array}{l}\text { The tumour increased to the size } \\
\text { of } 5 \mathrm{~cm} \times 3.5 \mathrm{~cm} \text {, metastasis to } \\
\text { lymphatic glands of the hepatic } \\
\text { hilum }\end{array}$ \\
\hline 20 & Cocker Spaniel & 9 & Female & $\begin{array}{l}\text { Hepato-cellular } \\
\text { carcinoma }\end{array}$ & $\begin{array}{l}\text { Disseminated tumours in hepatic } \\
\text { lobes }\end{array}$ & 66 & No change \\
\hline 21 & Mixed breed & 13 & Female & $\begin{array}{l}\text { Hepato-cellular } \\
\text { carcinoma }\end{array}$ & Infiltration & $\begin{array}{c}32 \\
\text { (euthanasia) }\end{array}$ & $\begin{array}{l}\text { Metastasis to lymphatic glands of } \\
\text { the hepatic hilum }\end{array}$ \\
\hline 22 & Mixed breed & 15 & Male & Hepato-blastoma & Single tumour $4.0 \mathrm{~cm} \times 4.5 \mathrm{~cm}$ & $\begin{array}{c}98 \\
\text { (euthanasia) }\end{array}$ & $\begin{array}{l}\text { The tumour increased to the size } \\
\text { of } 7 \mathrm{~cm} \times 4.5 \mathrm{~cm}\end{array}$ \\
\hline 23 & Mixed breed & 11 & Male & $\begin{array}{l}\text { Neuro-endocrine } \\
\text { tumour }\end{array}$ & Single tumour $2.2 \mathrm{~cm} \times 2.6 \mathrm{~cm}$ & 72 & $\begin{array}{l}\text { The tumour increased to the size } \\
\text { of } 5 \mathrm{~cm} \times 2.5 \mathrm{~cm} \text {, metastasis in } \\
\text { the lungs }\end{array}$ \\
\hline 24 & German Shepherd & 14 & Female & Biliary duct cancer & Infiltration & 45 & Metastasis in the lungs \\
\hline
\end{tabular}


In all cases, the owners did not give consent to surgery and chemotherapy, arguing that their dogs were too old for this kind of treatment. Depending on the applied treatment method, the dogs were divided into two groups: group I dogs receiving a preparation based on capsaicin-containing dried habanero pepper extract, group II - animals, whose owners chose not to apply any veterinary intervention - the dogs were left untreated.

Animals that died in the follow-up period or were euthanised due to their deteriorating general condition (six dogs in group I and three dogs in group II) were subjected to an autopsy and liver samples were collected for histopathological examination in order to determine the type of neoplasm and find out whether the tumour was primary or secondary.

Only dogs with primary hepatic cancer were included in further clinical analysis, which reduced the number of the studied animals to 24 . Sixteen dogs were classified to group I and eight dogs to group II. The age and gender of the animals and the type of the diagnosed tumour were presented in table 1 .

Clinical examination. A general condition assessment of the animals used in the study was performed on the basis of clinical observations and data obtained during an interview. The animals were brought to veterinary practices with various problems, such as loss of appetite, jaundice, anaemia and abdominal tenderness. Blood for biochemical and haematological analyses was collected from all dogs. The haematological examination was performed using an Exigo Boule analyser (Sweden), whereas the biochemical examination was conducted using a Mindray BS-300 analyser (Poland). Throughout the study period, all group I animals were receiving a dietary supplement based on habanero peppers (in the form of capsules containing $6.25 \mu \mathrm{g}$ capsaicin per $10 \mathrm{~kg}$ of body weight). The permission of the owners of each of the animals was obtained for the application of the dietary supplement.

The survival time (in days) was determined for all studied animals, beginning from the moment of making the diagnosis on the basis of ultrasound examination and, in case of group I animals, the initiation of treatment.

Ultrasound examination. The ultrasound examination was performed using Mindray DC 7 and Esaote My Lab Twice devices with linear and micro convex probes. Each neoplastic lesion was examined in at least two mutually perpendicular cross-sections. The tumour size was evaluated by measuring its length and width. In every studied animal, the first follow-up ultrasound examination was performed after 4-6 weeks, depending on the clinical condition, and the next one after the following three months.

Anatomopathological examination. The autopsy was performed according to standard protocol. Samples of the liver tumour were obtained for histopathological examination. They were fixed in $10 \%$ buffered formalin with $\mathrm{pH}=7.2$ and then immersed in increasing concentrations of alcohol solutions, acetone and xylene to paraffin blocks in a tissue processor (Leica TP-20). Tissue sections with a thickness of $4 \mu \mathrm{m}$, performed on a microtome (Leica SR-200), were transferred onto slides. The preparations for the histopathological examination were stained with hematoxylin and eosin (HE) and assessed using a light microscope (Nikon Eclipse E-600) following the WHO histological classification for cancers (12).

Statistical analysis. The Mann-Whitney rank test was used to demonstrate the differences in the lifespan of dogs in group I (which received the habanero pepper supplement) and dogs in group II (untreated). Changes were considered statistically significant at $\mathrm{p}<0.05$. The Statistica 10.0 PL software was used for the calculations.

\section{Results and discussion}

Clinical observation. The haematological examination demonstrated leucocytosis in twelve of sixteen dogs from group I (75\%) and in seven of eight dogs from group II $(87.5 \%)$, anaemia was found in 7 dogs from group I $(43.75 \%)$ and 3 dogs from group II $(37.5 \%)$, and thrombocytopaenia in $10 \mathrm{dogs}$ from group I (62.5\%) and 7 dogs from group II (87.5\%). The biochemical examination demonstrated the increase of alanine aminotransferase (ALT) and alkaline phosphatase (AP) activity in all dogs in both groups, the increase of asparagine aminotransferase (AST) activity in 10 dogs from group I $(62.5 \%)$ and 6 dogs from group II $(75 \%)$, and the increase of bilirubin concentration in 8 dogs from group I (50\%) and 3 dogs from group II (37.5\%) (Tab. 2). Changes of the parameter values detected in haematological and biochemical examinations persisted for the entire study period. The administration of the dietary supplement containing capsaicin to dogs from group I did not affect the results of complete blood count and the biochemical analysis.

Anatomopathological examination result. In group I, the autopsy demonstrated that in seven dogs the neoplastic process had the form of hepatic tissue infiltration and in five dogs there were single liver tumours, while in four patients the process was disseminated and involved all hepatic lobes. In group II, three dogs had single liver tumours, in three dogs the process was disseminated and involved the entire organ, while in two dogs the lesion was of an infiltrative character. The histopathological examination of the samples collected from group I dogs showed hepatocellular carcinoma $(11 / 16 ; 68.75 \%)$ (Fig. 4), biliary duct cancer (4/16; 25\%) (Fig. 5) and sarcoma $(1 / 16 ; 6.25 \%)$. In group II, five dogs had hepatocellular cancer $(62.5 \%)$ and only single dogs had biliary duct cancer $(12.5 \%)$, neuroendocrine tumour $(12.5 \%)$ and hepatoblastoma $(12.5 \%)$. In nine dogs from group I and five dogs from group II, metastatic lesions were found in the lymphatic nodes of the hepatic hilum or in the lungs (Tab. 1). Bearing in mind that the study group consisted of $16 \mathrm{dogs}$, and the control group of 8 animals, the differences in the appearance of metastases between both these groups are not statistically significant and do not indicate that the administration of the supplement based on habanero peppers containing capsaicin significantly prevented the formation of 
Tab. 2. Results of haematological and biochemical tests performed on dogs used in the study

\begin{tabular}{|c|c|c|c|c|c|c|c|c|}
\hline $\begin{array}{l}\text { No. } \\
\text { of the } \\
\text { dog }\end{array}$ & $\begin{array}{c}\text { RBC } \\
\left(\times 10^{12} /\right)\end{array}$ & $\begin{array}{c}\mathrm{Hb} \\
(\mathrm{g} / \mathrm{dl})\end{array}$ & $\begin{array}{l}\text { WBC } \\
\left(10^{9} / l\right)\end{array}$ & $\begin{array}{c}\text { PLT } \\
\left(10^{9} / l\right)\end{array}$ & $\begin{array}{l}\text { AST } \\
\text { (U/I) }\end{array}$ & $\begin{array}{l}\text { ALT } \\
\text { (U/I) }\end{array}$ & $\begin{array}{l}\text { ALP } \\
\text { (U/l) }\end{array}$ & $\begin{array}{c}\text { Total } \\
\text { bilirubine } \\
\text { (mg/dl) }\end{array}$ \\
\hline \multicolumn{9}{|c|}{ Group I } \\
\hline 1 & 4.7 & 11.0 & 19.4 & 87 & 93 & 73 & 302 & 0.84 \\
\hline 2 & 6.8 & 13.6 & 12.8 & 144 & 26 & 98 & 227 & 0.92 \\
\hline 3 & 5.2 & 10.4 & 16.2 & 106 & 75 & 70 & 256 & 0.81 \\
\hline 4 & 7.1 & 15.8 & 21.3 & 95 & 102 & 55 & 188 & 0.24 \\
\hline 5 & 5.7 & 15.2 & 18.2 & 424 & 8 & 92 & 160 & 0.33 \\
\hline 6 & 5.8 & 12.6 & 13.8 & 226 & 24 & 78 & 203 & 0.67 \\
\hline 7 & 6.3 & 17.1 & 19.1 & 299 & 47 & 59 & & 0.11 \\
\hline 8 & 3.5 & 9.8 & 23.0 & 104 & 102 & 103 & 108 & 0.68 \\
\hline 9 & 6.6 & 12.6 & 19.5 & 163 & 18 & 64 & 244 & 1.10 \\
\hline 10 & 4.1 & 10.3 & 19.5 & 284 & 27 & 128 & 172 & 0.28 \\
\hline 11 & 7.0 & 17.2 & 22.1 & 306 & 15 & 95 & 158 & 0.51 \\
\hline 12 & 5.9 & 15.2 & 10.6 & 72 & 76 & 88 & 363 & 0.34 \\
\hline 13 & 3.3 & 8.3 & 23.3 & 79 & 93 & 92 & 401 & 0.60 \\
\hline 14 & 6.7 & 17.3 & 15.1 & 118 & 84 & 60 & 170 & 1.00 \\
\hline 15 & 4.0 & 9.9 & 18.8 & 321 & 110 & 84 & 463 & 0.83 \\
\hline 16 & 4.1 & 11.2 & 25.1 & 37 & 83 & 115 & 205 & 0.54 \\
\hline \multicolumn{9}{|c|}{ Group II } \\
\hline 17 & 7.3 & 16.0 & 17.3 & 46 & 25 & 64 & 224 & 0.18 \\
\hline 18 & 3.7 & 11.3 & 19.6 & 284 & 88 & 89 & 402 & 0.36 \\
\hline 19 & 8.1 & 15.8 & 18.5 & 110 & 112 & 133 & 183 & 0.57 \\
\hline 20 & 3.9 & 8.1 & 24.1 & 88 & 49 & 129 & 315 & 1.31 \\
\hline 21 & 6.4 & 14.2 & 18.2 & 189 & 47 & 83 & 199 & 0.93 \\
\hline 22 & 5.8 & 12.9 & 9.4 & 56 & 95 & 57 & 307 & 0.12 \\
\hline 23 & 4.2 & 10.3 & 23.0 & 80 & 28 & 80 & 460 & 0.45 \\
\hline 24 & 6.1 & 15.6 & 17.7 & 137 & 45 & 120 & 199 & 0.81 \\
\hline Range & $5.5-8.5$ & $12-18$ & $6-16.5$ & $200-500$ & $1-37$ & $3-51$ & $20-155$ & $\leq 0.6$ \\
\hline
\end{tabular}

metastases. Most metastases (in both groups) were associated with hepatocellular carcinoma.

The demonstration of the correlation between the administration of a dietary supplement based on habanero peppers containing capsaicin to dogs and the animal survival. Survival of dogs in group I, from the moment of neoplasm diagnosis by means of ultrasound examination and the introduction of the dietary supplement containing capsaicin, was 54 to 285 days (178.6 days on average). Survival of dogs in group II was 32-128 days (76.5 days on average). The differences are statistically significant $(p=0.043)$ and they indicate that the mere administration of a capsaicincontaining preparation significantly improves survival in dogs with hepatic cancer compared to untreated dogs. Moreover, in none of the dogs classified to group I that had single tumours did the size of the lesion increase during supplement administration, and in the case of two dogs that were receiving the preparation for a long time (188 and 285 days), their liver tumours actually shrank. In comparison, in all dogs from group II that had single tumours, the size of the lesions increased in the course of their observation (Tab. 1).

Preliminary clinical observations indicate that the capsaicin-containing habanero pepper preparation exhibits a favourable effect on different primary hepatic tumours in dogs and it

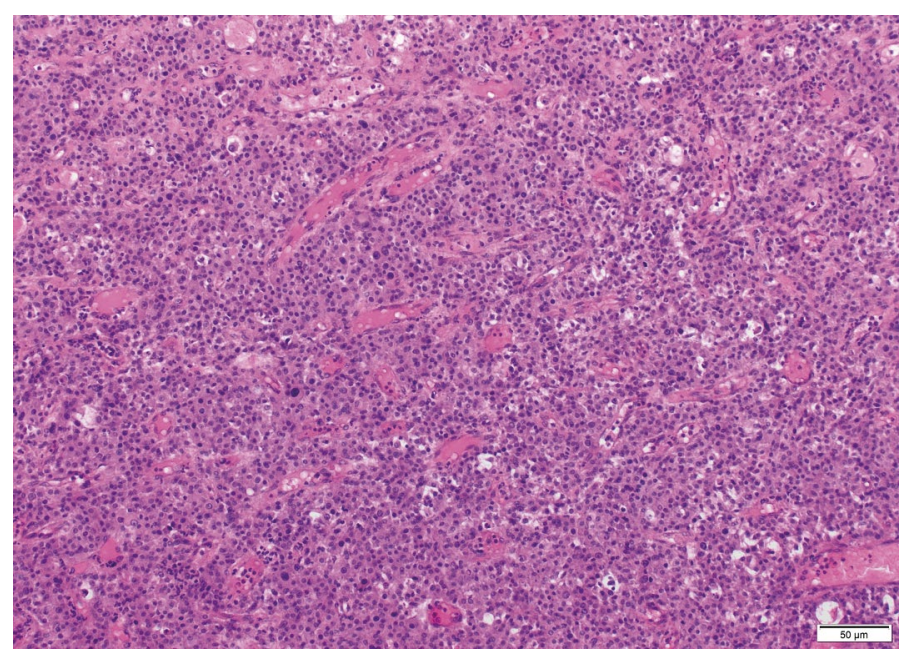

Fig. 4. Results of the histopathological examination of the liver of the dog used in the study - hepatocellular carcinoma. There is pleomorphism of neoplastic hepatocytes. Staining HE, magn. $\times 100$

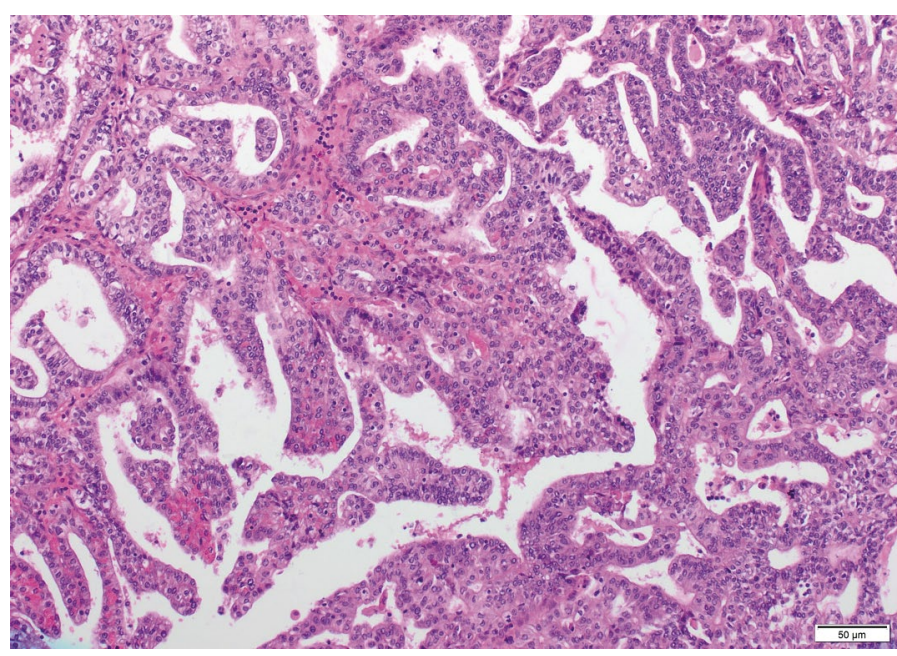

Fig. 5. Results of the histopathological examination of the liver of the dog used in the study - biliary duct cancer. The neoplasm is composed of pleomorphic cells that form crude ducts. Staining HE, magn. $\times 100$ 
is relatively well tolerated by the animals. None of the dogs from group I receiving the supplement had symptoms of intolerance in the form of diarrhoea or vomiting. Nor did the irregularities in haematological or biochemical examination results observed in dogs at the time of enrolment intensify, as it was observed in some dogs with mammary gland neoplasms receiving dried habanero peppers (1).

Out of 16 animals with hepatic cancer receiving the dietary supplement based on pepper extract, in two dogs the size of their single tumours decreased, and in the remaining animals the development of the neoplastic process was arrested. In comparison, in all untreated control group dogs with single liver tumours their size increased during the course of observation. This demonstrates that the habanero pepper extract may inhibit tumour growth, and even induce its resorption. This may result from the induction of apoptosis by capsaicin included in the extract. Apoptosis of cancer cells is a consequence of inhibition of electron transport from NADH to ubiquinone by capsaicin, or its direct bonding with coenzyme $\mathrm{Q}$, which causes the change of electron flow direction and creation of reactive oxygen forms in excess. The consequence of this is the dispersion of transmembrane potential in mitochondria (22) which is crucial for the functioning of these organelles. Apoptosis starts from the transmembrane potential breakdown, while active oxygen forms may cause damage to the structure and impairment of the mitochondrial function and, consequently, the death of the cancer cell.

Apoptosis of cancer cells that takes place under the influence of capsaicin is related with this alkaloid stimulating the transcription of, for instance, the p53 gene. Such a mechanism of operation, accompanied by DNA fragmentation in cancer cells, was confirmed in in vitro conditions in the case of stomach cancer cells (14). According to Yang et al. (26), the anti-cancer effect of capsaicin is related not only to the fact that this substance induces apoptosis of cancer cells, but also to the direct effect on such cells, resulting in their death. In the course of in vitro examinations carried out on T24 cancer cells of the bladder in mice, it was determined that depending on the dose, capsaicin may lead to depolarisation of the mitochondrial membrane, the result of which is the death of a cell (not apoptosis). It is suggested that this alkaloid may be used in the treatment of urinary bladder cancer.

The case is similar with prostate cancer, for which this alkaloid shows strong anti-proliferation influence. Capsaicin induces apoptosis both in cancer cells with androgen receptor (AR) and without it. At the same time, it increases the concentration of p53, Bax and p21 proteins, which participate in the control of the cell cycle. The discussed substance decreases the expression of PSA, (prostate-specific antigen) which is the most well-known human serine protease from the family of kallikreins, produced in the prostate and present in the blood in heightened concentration, e.g. in the case of prostatitis, benign prostatic hyperplasia, or prostate cancer (18).

Another aspect of the anticancer effect of capsaicin is related to blocking angiogenesis. Angiogenesis is a key stage of tumour development and metastasis. The proliferation of cancer cells increases their need for oxygen supply. After some point, the existing vascular system is unable to provide amounts of oxygen sufficient for the cancer cells. Therefore, the formation of additional blood vessels is necessary. The study by Min et al. (17) confirmed without doubt that capsaicin blocks angiogenesis both in in vitro and in vivo conditions. The alkaloid works as an inhibitor of angiogenic paths induced by vascular endothelial growth factor (VEGF). VEGF is the main regulator of angiogenesis not only in cancer cells, but also in healthy cells. Therefore, it is suggested that capsaicin may be used for angiogenesis-dependent diseases.

In human medicine, capsaicin has been used in the treatment of various types of cancer. Its ability to block VEGF-induced path was used, for example, in the therapy of lung cancer. Apart from reducing angiogenesis, the alkaloid also contributed to oxidative damage of DNA of the cancer cells in the lungs, and inhibited their proliferation $(3,4)$. In the case of cholangiocarcinoma, capsaicin showed an anti-migration and anti-invasion effect by blocking the activity of NF- $\kappa \mathrm{B}$ p65, which results in lowered expression of MMP-9 $(15,25)$.

The discussed alkaloid also induced apoptosis of cancer cells in acute lymphoblastic (lymphoid) leukaemia (27) and was efficient in the therapy of neoplasms of the pancreas $(20,21)$, colon and rectum $(6)$, and urinary bladder (27).

In veterinary medicine, the anticancer efficiency of capsaicin was studied mostly on laboratory animals serving as models for human medicine. It was proved that the alkaloid is efficient in the therapy of prostate adenocarcinoma in mice and prevents the development of benzo(a)pyrene-induced lung cancer in mice (2).

The most recent study of Adaszek et al. (1) proved the anti-cancer efficacy of the capsaicin-containing habanero pepper extract in dogs. The study was conducted on a group of 50 dogs diagnosed with tumours, and 20 dogs forming a control group. All animals were administered with a dietary supplement based on habanero pepper extract containing capsaicin. Observations were conducted for a period of six months, during which time the general condition of the animals administered with the extract was monitored, and haematological as well as biochemical examinations were conducted at 2-week intervals in order to assess the tolerance of the animals to the extract. In the animals of the test group, tumour sizes were measured at monthly intervals. After the end of observations, the tumours were removed and subjected to histopatho- 
logical tests. As a result of habanero pepper extract administration, the tumour size decreased by $5-50 \%$ in $15 \mathrm{dogs}$, the size of tumours remained unchanged in 29 dogs, whereas tumour size increased by $10-30 \%$ in 5 animals despite the administration of the extract. The extract was well tolerated by the animals.

The authors' observations confirmed that the administration of a preparation based on dried habanero peppers to dogs with primary hepatic cancer significantly improves the survival of animals compared to the control group dogs that did not receive any treatment (178.6 days vs. 76.5 days). Although this time is shorter than the mean survival time of dogs with primary hepatic cancer subjected to chemotherapy using CHOP, which is 8-12 months (9), the analysis of data allows us to claim that dried habanero peppers containing capsaicin may constitute an alternative solution for cancer patients in whom it is not possible to apply chemotherapy for either medical or economic reasons. It should also be kept in mind that the prognosis in the case of primary hepatic cancer, regardless of the applied treatment method (surgery, chemotherapy, alternative), is always unfavourable, thus two-and-a-half-times longer survival compared to control animals, achieved at a relatively low cost of the dietary supplement, seems important especially for less wealthy dog owners.

The preliminary clinical observations by the authors indicate that the capsaicin-containing habanero pepper extract exhibits favourable effects on liver tumours in dogs and is well tolerated by the animals, thus the obtained results are a good sign for future studies on alternative medications used in dog oncology.

\section{References}

1. AdaszekE., Gadomska D., Staniec M., Gotyński M., Eyp P., ZiętekJ., Różańska D., Orzelski M., Śmiech A., Winiarczyk S.: Clinical assessment of the anti-cancer activity of the capsaicin-containing habanero pepper extract in dogs - preliminary study. Med. Weter. 2017, 73, 404-411.

2. Anandakumar P., Kamaraj S., Jagan S., Ramakrishnan G., Asokkumar S., Naveenkumar C., Raghunandhakumar $S$., Devaki T.: Capsaicin inhibits benzo(a)pyrene-induced lung carcinogenesis in an in vivo mouse model. Inflamm. Res. 2012, 61, 1169-1175.

3. Brown K. C., Witte T. R., Hardman W. E., Luo H., Chen Y. C., Carpenter A. B., Lau J. K., Dasgupta P.: Capsaicin displays anti-proliferative activity against human small cell lung cancer in cell culture and nude mice models via the E2F pathway. PLoS ONE 2010, 5, 10243.

4. Chakraborty S., Mazumdar M., Mukherjee S., Bhattacharjee P., Adhikary A. Manna A., Chakraborty S., Khan P., Sen A., Das T.: Restoration of p53/miR34 a regulatory axis decreases survival advantage and ensures Bax-dependent apoptosis of non-small cell lung carcinoma cells. FEBS Lett. 2014, 588, 549-559.

5. Chen X., Tan M., Xie Z., Feng B., Zhao Z., Yang K., Hu C., Liao N., Wang T., Chen D., Xie F., Tang C.: Inhibiting ROS-STAT3-dependent autophagy enhanced capsaicin-induced apoptosis in human hepatocellular carcinoma cells. Free Radic. Res. 2016, 50, 744-755.

6. Clark R., Lee. J., Lee S. H.: Synergistic anticancer activity of capsaicin and 3,3'-Diindolylmethane in human colorectal cancer. J. Agric. Food Chem. 2015, 63, 4297-4304.

7. Cromer B. A., McIntyre P.: Painful toxins acting at TRPV1. Toxicon 2008, 51, 163-173.

8. Díaz-Laviada I., Rodríguez-Henche N.: The potential antitumor effects of capsaicin. Prog. Drug Res. 2014, 68, 181-208.
9.Dobson J., Lascelles D.: BSAVA Manual of Canine and Feline Oncology. BSAVA, Quedgeley, Gloucester 2011.

10. Gilardini Montani M. S., D'Eliseo D., Cirone M., Di Renzo L., Faggioni A., Santoni A., Velotti F.: Capsaicin-mediated apoptosis of human bladder cancer cells activates dendritic cells via CD91. Nutrition 2015, 31, 578-581.

11. Golyński M., Balicki I., Lutnicki K., Smiech A., Adamek L., Szczepanik M., Wilkolek P., Brodzki A., Adaszek L.: Systemic and local effects of intragastric administration of the habanero fruit (Capsicum chinense Jacquin c.v.) in rats. J. Physiol. Pharmacol. 2015, 66, 259-265.

12. Head K. W., Cullen J. M., Dubielzig R. R., Else R. W., Misdorp W., Patnaik A. K., Tateyama S., van der Gaag I.: Histological classification of tumors of the alimentary system of domestic animals. Armed Forces Institute of Pathology, Washington, D.C. 2003.

13. Huang S. P., Chen J. C., Wu C. C., Chen C. T., Tang N. Y., Ho Y. T., Lo C., Lin J. P., Chung J. G., Lin J. G.: Capsaicin-induced apoptosis in human hepatoma HepG2 cells. Anticancer Res. 2009, 29, 165-174.

14. Kim J. D., Kim J. M., Pyo J. O., Kim S. Y., Kim B. S., Yu R., Han I. S.: Capsaicin can alter the expression of tumor forming-related genes which might be followed by induction of apoptosis of a Korean stomach cancer cell line, SNU-1. Cancer Lett. 1997, 120, 235-241.

15. Lee G. R., Jang S. H., Kim C. J., Kim A. R., Yoon D. J., Park N. H., Han I. S.: Capsaicin suppresses the migration of cholangiocarcinoma cells by downregulating matrix metalloproteinase-9 expression via the AMPK-NF-kappaB leomorphi pathway. Clin. Exp. Metastasis 2014, 31, 897-907.

16. Mann C. D., Neal C. P., Garcea G., Manson M. M., Dennison A. R., Berry D. P.: Phytochemicals as potential chemopreventive and chemotherapeutic agents in hepatocarcinogenesis. Eur. J. Cancer Prev. 2009, 18, 13-25.

17. Min J. K., Han K. Y., Kim E. C.: Capsaicin inhibits in vitro and in vivo angiogenesis. Cancer Res. 2004, 64, 644-651.

18. Mori A., Lehmann S., O’Kelly J., Kumagai T., Desmond J. C., Pervan M., McBride W. H., Kizaki M., Koeffler H. P.: Capsaicin, a component of red peppers, inhibits the growth of androgen-independent, p53 mutant prostate cancer cells. Cancer Res. 2006, 15, 3222-3229.

19. O'Neil R. G., Brown R. C.: The vanilloid receptor family of calcium-permeable channels: molecular integrators of microenvironmental stimuli. News Physiol. Sci. 2003, 18, 26-31.

20. Pramanik K. C., Fofaria N. M., Gupta P., Srivastava S. K.: CBP-mediated FOXO-1 acetylation inhibits pancreatic tumor growth by targeting SirT. Mol. Cancer Ther. 2014, 13, 687-698.

21. Skrzypski M., Sassek M., Abdelmessih S., Mergler S., Grotzinger C., Metzke D., Wojciechowicz T., Nowak K. W., Strowski M. Z.: Capsaicin induces cytotoxicity in pancreatic neuroendocrine tumor cells via mitochondrial action. Cell Signal. 2014, 26, 41-48.

22. Surh Y. J.: More than spice: capsaicin in hot chili peppers makes tumor cells commit suicide. J. Natl. Cancer Inst. 2002, 94, 1263-1265.

23. Venier N. A., Colquhoun A. J., Sasaki H., Kiss A., Sugar L., Adomat H., Fleshner N. E., Klotz L. H., Venkateswaran V.: Capsaicin: a novel radio-sensitizing agent for prostate cancer. Prostate 2015, 75, 113-125.

24. Venier N. A., Yamamoto T., Sugar L. M., Adomat H., Fleshner N. E., Klotz L. H., Venkateswaran $V$. : Capsaicin reduces the metastatic burden in the transgenic adenocarcinoma of the mouse prostate model. Prostate 2015, 75, 1300-1311.

25. Wutka A., Palagani V., Barat S., Chen X., El K. M., Gotze J., Belahmer H., Zender S., Bozko P., Malek N. P.: Capsaicin treatment attenuates cholangiocarcinoma carcinogenesis. PloS ONE 2014, 9, 95605.

26. Yang D., Luo Z., Ma S., Wong W. T., Ma L., Zhong J., He H., Zhao Z., Cao T., Yan Z., Liu D., Arendshorst W. J., Huang Y., Tepel M., Zhu Z.: Activation of TRPV1 by dietary capsaicin improves endothelium-dependent vasorelaxation and prevents hypertension. Cell Metab. 2010, 4, 130-141.

27. Zheng J., Zhou Y., Li Y., Xu D. P., Li S., Li H. B.: Spices for prevention and Treatment of Cancers. Nutrients 2016, 8, 495 .

Corresponding author: Lukasz Adaszek, DVM, PhD hab. prof. UP, Głęboka 30, 20-612 Lublin, Poland; e-mail: ukaszek0@wp.pl 